\title{
ORGANISATION AND DIVERSIFICATION OF THE EDUCATIONAL MARKET IN POLAND: THE CASE OF THE POZNAŃ AGGLOMERATION
}

\author{
MarZena WaLASZEK, Edyta BĄKOWSKA \\ Institute of Socio-Economic Geography and Spatial Management, \\ Adam Mickiewicz University in Poznań, Poland
}

Manuscript received: March 2, 2015

Revised version: April 18, 2016

\begin{abstract}
WALASZEK M., BĄKOWSKa E., 2016. Organisation and diversification of the educational market in Poland: The case of the Poznań agglomeration. Quaestiones Geographicae 35(2), Bogucki Wydawnictwo Naukowe, Poznań, pp. 105-114, 4 figs, 3 tables.
\end{abstract}

ABSTRACT: The political changes in Poland after 1989 affected the formation of a self-reliant society. One of the results was the decentralisation of public tasks in the field of education, with the relevant competences transmitted to local governments. Since then, communes have been responsible for ensuring equal access to public education, but at the same time a non-public education market has been developing. Important for changes in the Polish educational system was also a reform started in 1999 which led to the transformation of the two-level system of education existing since 1968 into a three-level structure.

The first non-public schools began to form as an alternative to public ones. Currently, non-public schools are mainly run by non-governmental organisations, religious institutions or social associations. In the general opinion, the quality of education in non-public schools is higher than in public ones (smaller classes, better contact between student and teacher, an individual approach to each student). In the face of education-model changes it is important to create a wide range of learning opportunities for everyone. It is also not about competition, but cooperation among all institutions involved in education provision. In this article, the progressive diversification of the educational market is presented on the example of the Poznań agglomeration.

A diversified educational system, its commercialisation, and the creation of new educational opportunities for children and young people beyond the basic programme of education are undoubtedly benefits for the Polish society. The growing competition among the wide range of educational institutions (also taking into account institutions organising extra-curricular classes), from a theoretical point of view, should help to improve the quality of education in the entire market of educational services. As a consequence, these trends, together with demographic changes, may invite the question about the prospects of public schools in their present form in the future.

KEY WORDS: educational system, compulsory education, decentralisation of education, market for educational services, Poznań agglomeration

Corresponding author: Marzena Walaszek, Institute of Socio-Economic Geography and Spatial Management, Adam Mickiewicz University in Poznań, Dzięgielowa 27,61-680 Poznań, Poland; e-mail: marwal@amu.edu.pl

\section{Introduction}

The political changes in Poland which took place after 1990 have significantly transformed the provision of social services, including education. The political and economic transformation brought about the delegation of public tasks to the local or the regional level and created new 
social demands and expectations. The new civil society started to expect local governments not only simply to provide services, but also to guarantee their high quality and universal accessibility to citizens. It should be emphasised that in Poland the citizen's right to education is a constitutional law. The framework of the operation of the educational system was set up by the Educational System Act of 7 September 1991. It defines the obligatory duties of local governments concerning the local school system as well as the spatial location of schools.

According to Dolata (2005: 2-6), the Polish educational system in the communist period had the characteristics of the Soviet model, but also some unique features. According to this author, the main features of the socialist model of Polish education were strong centralisation and politicisation, high ideologisation, and the desire to maintain a specified social structure. Also common was only a marginal presence of non-state schools because of the negative attitude of the communist government towards private ownership and the fear of losing political control over the ideological mission of public education.

The transformation of the educational system from the centrally controlled to a decentralised model started in the early 1990s. The decentralisation began with the transfer of kindergartens to the care of communes in 1990 and ended in 1999 with the transfer of upper secondary schools to higher-level administrative units, poviats, created after the administration reform. Currently, the Polish educational system is one of the most decentralised ones in Europe (Herbst 2012: 13-18). The result of the decentralisation is full autonomy of local governments in education management. Local authorities can create various educational policies or specify their implementation in local strategic documents. Creating this type of documents and policies is reasonable considering Poland's decreasing population and the negative demographic changes taking place there (low fertility rates and a decreasing number of pupils).

Since the 1990s the Polish educational system has constantly been changing. In 1999 the most important reform of the educational system was introduced. The result was the creation of a three-stage system of education: 8-year primary schools were liquidated, replaced by 6-year primary schools and 3-year lower-secondary ones.
Another significant change has been the creation of external examinations at the end of primary and lower-secondary schools, which have formally become a ticket to education at higher levels. A recent change, criticised by parents and numerous social organisations, was the lowering of the school age. In 2015 primary school started to be attended by children born in 2009 , so their age will fall from 7 to 6 years.

The main aim of this article is to present the process of decentralisation of the Polish educational system and its current implications at the national and the local level (the case of the Poznan agglomeration). The main determinants and conditions of the Polish educational system will be presented against the background of the political transformation and socio-economic processes taking place in Poland in the recent years. Current problems of the system will be discussed as well as possible ways of solving them under the existing law.

\section{Determinants of the educational services market in Poland}

The situation of the educational services market in Poland can be described in terms of the social, demographic, financial and legal factors presented in Table 1.

The country's radical legal and organisational transformation has unlocked the potential of educational institutions and created the framework for the development of new actors on the educational services market. The legislative changes of the 1990s connected with administrative and educational reforms, along with complementary reforms in the subsequent years, were among the most powerful determinants of the present situation of this market. The in-depth decentralisation of the educational system administration gave communes greater decisive power and caused new actors to emerge on the market (Local Government Act, Art. 7, Cl. 8, Poviat Government Act, Art. 4, Cl. 1, Voivodeship Government Act, Art 14, Cl. 1, Educational System Act, Art. 5a).

To meet high educational aspirations of citizens after 1989, the educational system in Poland had to adapt to their growing needs, resulting in a high level of education acquisition, both at 
Table 1. Selected determinants of the educational services market in Poland

\begin{tabular}{|c|c|c|c|}
\hline Social & Demographic & Financial & Legal \\
\hline $\begin{array}{l}\text { - high educational aspira- } \\
\text { tions of Polish citizens after } \\
1989 \\
\text { - growth of wealth } \\
\text { - labour market } \\
\text { - mobility } \\
\text { - expectations about the qual- } \\
\text { ity of teaching }\end{array}$ & $\begin{array}{l}\text { - low population growth } \\
\text { - demographic decline } \\
\text { - decreasing number } \\
\text { of children in school } \\
\text { districts } \\
\text { - } 2+1 \text { family } \\
\text { - DINKY syndrome }\end{array}$ & $\begin{array}{l}\text { - high running costs of } \\
\text { schools } \\
\text { - inadequate educational } \\
\text { subsidy } \\
\text { - public finances crisis } \\
\text { - low poviat incomes }\end{array}$ & $\begin{array}{l}\text { - educational system de- } \\
\text { centralisation } \\
\text { - legislative framework } \\
\text { for the development of } \\
\text { non-public education in } \\
\text { Poland } \\
\text { - quality of education } \\
\text { monitoring }\end{array}$ \\
\hline
\end{tabular}

Source: own compilation.

the higher and the compulsory levels. This resulted in one of the best performances in Europe in terms of young people's education. According to the OECD data of 2012 (OECD 2014a: 312), Poland has one of the highest school enrolment rates by age group, higher than the average for the OECD and EU-21 countries. What has to be emphasised, Poland acquired such results despite the unfavourable methodology employed, which takes into account different age groups in compulsory education than in Poland. According to the PISA 2012 report (prepared by OECD, 2014b: 5) the performance of Polish pupils at the age of 15/16 was found to be one of the best in the world: 12 th position in mathematics, 9 th in reading, and 8 th in science.

The monitoring of educational services in Poland is also a very important factor increasing competition and creating a more diversified market. According to Eurydice (2012: 39-45), based on Eurostat data, Poland is listed among countries with a high external evaluation of schools and pupils' performance, with the obligation for evaluation data at the regional level to be published periodically since 2009 .

Another reason for changes in the educational services market in Poland is local-government finances and running costs of schools. Despite the high autonomy of communes concerning educational expenses, reduced educational subsidies for local governments affected their ability to finance schools. Furthermore, growing maintenance costs of schools and the fact that the total public expenditure on education as a percentage of the GDP is one of the highest (Eurydice 2012: 15-98) greatly prompted the numerous decisions to transfer public schools to non-public entities, which, according to the Educational System Act, have the same right to receive an educational subsidy.
Important determinants of the market of educational services in Poland are also social and demographic changes. After 1989 Polish society began a transformation in the area of the quality of life and social position. As a result, a lower demographic growth rate, connected with delaying the decision to have the first child, caused a decrease in the number of children in school districts, the effect being a reduction in the state subsidy for schools while running costs remain the same. As a consequence, communes have to face the problem of financing the costs, which can directly lead to the closing of schools and distributing children among different school districts. However, the growing wealth of the Polish society can also be a factor in sending children to other, better performing schools, which are not always public. This is strongly connected with the socio-economic status (Mitch 2004: 290) and the awareness of the impact of education on the children's future position on the labour market.

\section{Organisation of the Polish educational system}

Education in Poland is divided into two systems which function under the supervision of two ministries: the Ministry of National Education and the Ministry of Science and Higher Education. The Ministry of National Educational is responsible for nearly all levels and types of education with the exception of higher education, which is the remit of the Ministry of Science and Higher Education. As a result, there are two separate systems: the educational system and the higher educational system (Fig. 1).

According to the Educational System Act (Official Gazette no. 95/1991, position 425 with later changes, Chapter 1, Art. 2), the educational 


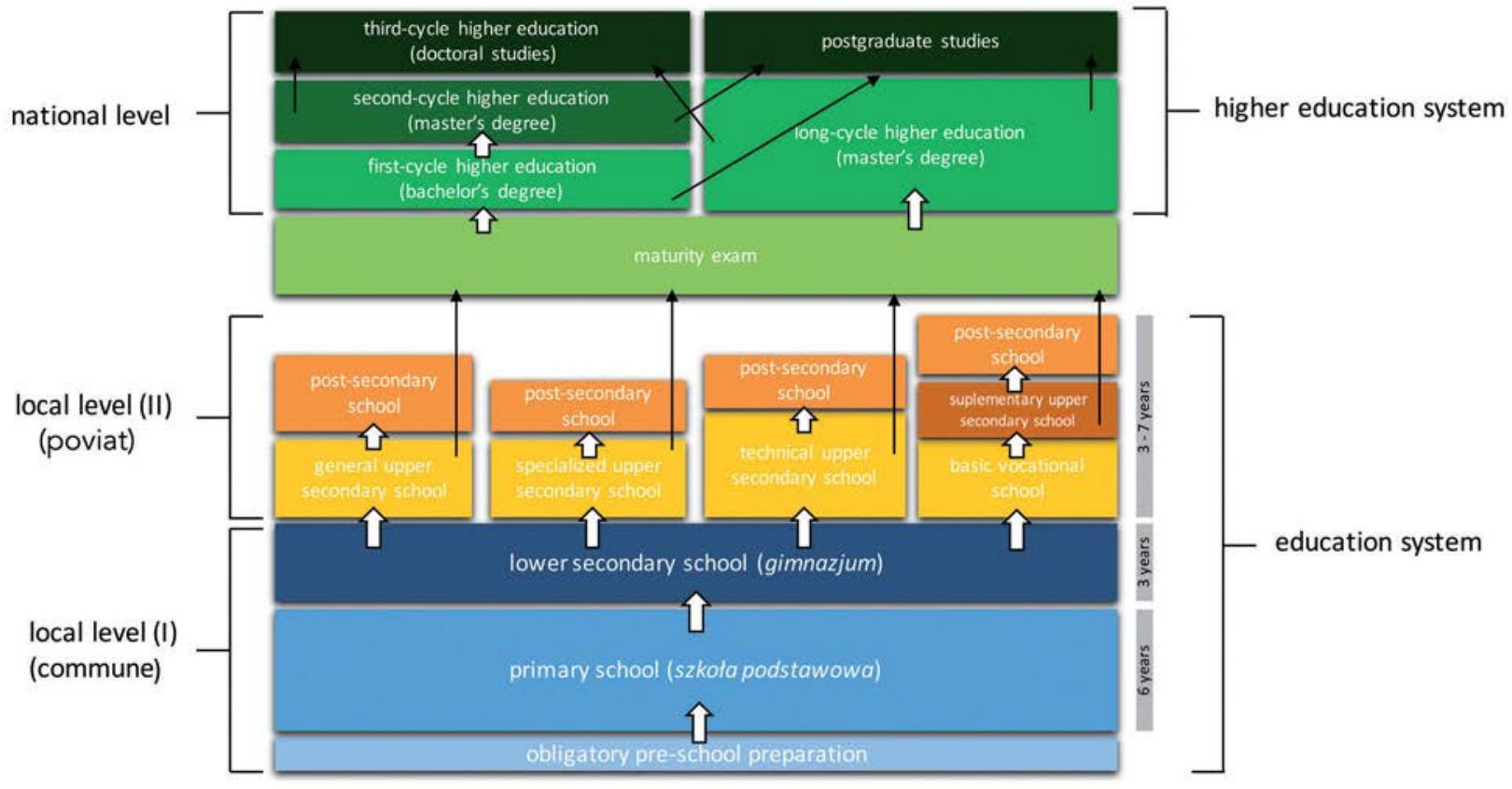

Fig. 1. Organisation of education in Poland.

Source: own compilation.

system in Poland consists of pre-school institutions, primary, lower-secondary, upper-secondary and post-secondary non-tertiary schools. However, in this paper the authors will focus only on the institutions which are responsible for compulsory education which are the following: preschools, primary schools and lower-secondary schools.

According to the Polish law (the Constitution of the Polish Republic, the Educational System Act), education in Poland is compulsory for children from the age of 5 until 18. As a result, in the basic, full-time system ${ }^{1}$, compulsory education consists of one year pre-school preparation in kindergartens and full-time education which is compulsory until the completion of lower-secondary school, but not beyond the age of 16 in the following levels and types of schools:

a. primary schools, including special primary schools, integration primary schools, primary schools with integration and sports classes, and sports primary schools, and

b. lower-secondary schools (gymnasiums), including special gymnasiums, integration gymnasiums, bilingual gymnasiums, gymna-

Part-time compulsory education for students aged 16-18 can be organised in school or non-school settings, like an apprenticeship system. siums with integration, bilingual, sports and vocational classes, and sports gymnasiums.

Since 2011 education is compulsory for children at the age of 5, who receive one year of pre-primary schooling (Eurydice 2014: 9-11). The next level of education - six years of primary school - commences for children from the age of 6 (European Commission 2014a: 5). Generally, for children aged 6 to 12 education in primary school is divided into:

a. stage 1 (grades 1-3) - 3-year early education based on integrated subjects,

b. stage 2 (grades 4-6) - 3-year education based on separate subjects for children aged 9 to 12, which finishes with an obligatory general test.

The last level of compulsory education - lower-secondary school - is for children at the age of 12 to 15/16 and finishes with an obligatory general examination which consist of three parts: the Humanities, Natural Sciences and a Modern Foreign Language (Centralna Komisja Egzaminacyjna 2015). Examination results strongly influence the admission to schools at the next level of education - upper secondary. The examination is regulated by the Central Examination Board and administered by Regional Examination Boards (Eurydice 2014: 9). However, because of the gradual introduction of a reform for children born in 2006, 2007 and the first half of 2008, 
compulsory education will last 11 years (an additional year of pre-school education), whereas for other children, both younger and older, compulsory education remains the same and last 10 years.

According to the European Commission's comparison (2014a: 5, 2014b: 8-27), the new organisation of compulsory educational system in Poland, including 1 year of pre-school at the age of 5, is similar to the systems in Greece, Croatia, Lithuania, Hungary, Bosnia and Herzegovina, the Netherlands, and Serbia. However, there are some differences in the duration of compulsory education in the countries listed above. Nevertheless, taking into account the age at which children start primary school, the same situation can be observed in 28 European Union countries. This shows the tendency to standardise educational systems, even though the Council of the European Union (2008) states that "the responsibility for the organisation and content of education and training systems rests with individual Member States".

At present (on the basis of the Educational System Act), lower-secondary school leavers can continue education in the following types of school: 3-year general upper secondary school (liceum ogólnokształcace), 3-year basic vocational school (zasadnicza szkoła zawodowa), 4-year technical upper secondary school (technikum), post-secondary school (szkota policealna) for graduates of upper secondary schools, and 3-year special school, which prepares pupils with disabilities for employment.
Apart from the above-mentioned schools, the educational system includes also a variety of supporting institutions, like education and practical training centres, art institutions, psychological support centres (providing pedagogical and psychological support), and other (Eurydice 2014: 75-81).

In order to face the society's growing educational needs: more learning opportunities and improving the quality of education after 1989, the educational system in Poland started to be reformed (OECD 2010: 6). Its current organisation results from major legislative changes enacted in the years 1990-1999 (together with complementary reforms in subsequent years) which were strongly connected with the country's administrative reform (the Local Government Act of 1990 along with the Act of 24 July 1998 Concerning the Introduction of the Basic Three-Tier Territorial Division of the Country), regulated in the Constitution of the Republic of Poland (1997) and basic legal acts in the matter of the organisation of education in Poland (the Educational System Act of 1991 and the Educational System Reform of 1999) (Fig. 2). The legislative framework for the decentralisation of the educational system resulted in the division of competences in its organisation (Table 2). Thus, the Ministry of National Education is responsible for the national educational policy, while the administration of education and the functioning of schools are decentralised. Schools providing compulsory education are administered by commune authorities, whereas upper secondary schools,

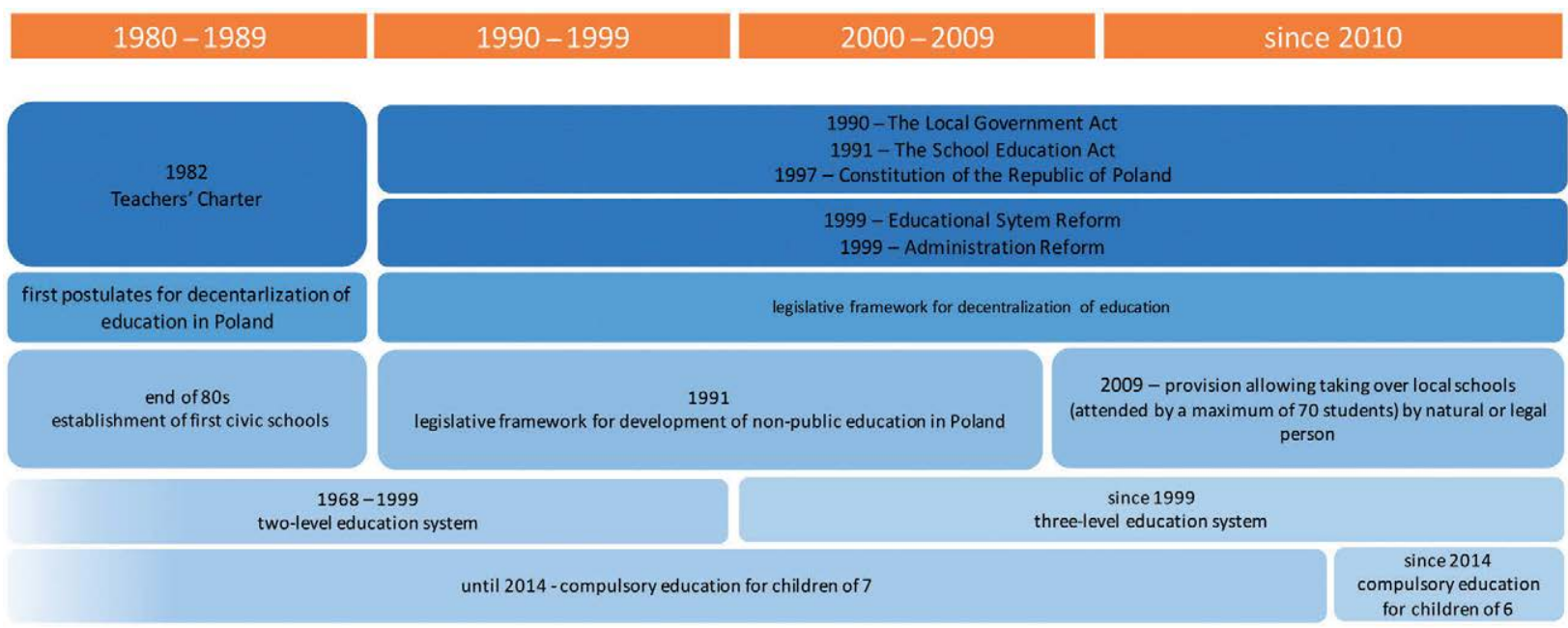

Fig. 2. Evolution of the educational system in Poland. Source: own compilation. 
Table 2. Levels of the organisation of education in Poland.

\begin{tabular}{|c|c|}
\hline $\begin{array}{l}\text { Level of organi- } \\
\text { sation }\end{array}$ & Competences \\
\hline National level & $\begin{array}{l}\text { Minister of National Education: } \\
\text { - administration of school system } \\
\text { - coordination of national educational policy } \\
\text { - requirements and procedures for admission to public schools } \\
\text { - general outlines of timetables for public schools } \\
\text { - core curricula for pre-school education and general education in particular types of school as } \\
\text { well as for vocational education } \\
\text { - rules for assessing and promoting pupils and for conducting tests and examinations } \\
\text { - organisational arrangements for school year and rules for remuneration of examiners and teachers }\end{array}$ \\
\hline \multirow[t]{2}{*}{ Regional level } & $\begin{array}{l}\text { Voivodeships: } \\
\text { - administration of the following educational institutions: teacher training and foreign-language } \\
\text { teacher training colleges (which are being phased out), colleges of social work, in-service teach- } \\
\text { er training institutions, educational resource centres, schools and related educational institu- } \\
\text { tions operating at regional and supra-regional levels }\end{array}$ \\
\hline & $\begin{array}{l}\text { Regional educational authorities - Superintendent of Education: } \\
\text { - pedagogical supervision over public and non-public schools, including regional in-service } \\
\text { teacher training } \\
\text { - general administration of education in particular voivodeships } \\
\text { - implementation of policy of Minister of National Education } \\
\text { - implementation of tasks defined in Educational System Act and in regulations relevant to par- } \\
\text { ticular voivodeships }\end{array}$ \\
\hline $\begin{array}{l}\text { Local level (II) - } \\
\text { poviat }\end{array}$ & $\begin{array}{l}\text { - running the following types of public schools and other educational institutions: upper-second- } \\
\text { ary and post-secondary schools; art schools; sports schools and schools for sports champions; } \\
\text { special primary and special lower-secondary schools; schools at prisons; youth detention cen- } \\
\text { tres and hostels for minors; counselling and guidance centres; and remedial centres }\end{array}$ \\
\hline $\begin{array}{l}\text { Local level (I) - } \\
\text { commune }\end{array}$ & $\begin{array}{l}\text { - establishing and administering public nursery schools (including special nursery schools), pri- } \\
\text { mary schools and lower-secondary schools }\end{array}$ \\
\hline
\end{tabular}

Source: own compilation on the basis of Eurydice (2014: 11-13).

which are not compulsory, are administered by poviat authorities (Fig. 1).

\section{Legal and organisational basis of the educational services market}

The implementation of educational tasks is one of the most important challenges for local governments. It should stimulate the development of self-government, and more broadly - local development (Przyszczypkowski 2010: 41-63). In local development policy, public services, including educational ones, are treated as an instrument of this policy, hence they should be regarded as an essential condition of development (Kuźnik 2012: 17-24). The goals of local educational policies should be identifying priorities for the development of education, ensuring equal access to educational institutions, creating favourable conditions of teaching, and ensuring a high quality of education.
In Poland, the most important decisions concerning the reorganisation of the school network are taken at the local level; this applies in particular to closing and opening new schools. In addition, local governments are equipped with many legal instruments for conducting a local educational policy. Among them should be mentioned in particular:

- organisational instruments: changing school districts, setting up or liquidating schools, setting the number of children attending a school's branches, changing profiles of education,

- financial instruments: a policy of employment, supervision and control of school finances, determining the remuneration of teachers, and

- legal instruments: the transmission of public schools to private operators.

Currently, the biggest problems of the Polish educational market are a dramatic drop in the number of children of school age, the need to adapt the school network at the local level to the 
declining number of pupils (which often happens via the liquidation of schools), and a yearslong systematic increase in outlays for education with a simultaneous decline in the number of pupils. In the years 1999-2013 the number of primary schools decreased from 16 thous. to 13 thous. $(18.75 \%)$, while the expenditure on primary education increased from 473,500 thous. to 930,000 thous. zlotys (96\%). Reasonable education management requires a concerted action of the state and local governments in the coming years. The delegation of educational tasks to non-state school operators is of no little significance here.

The outlays for education absorb a significant part of the budgets of communes and poviats, which implies a need for efficient management of the available financial resources. Unfortunately, the educational subsidy transferred to local government units is not sufficient to fully cover the cost of education. As a result of the demographic decline, many local governments have to close schools, which brings protests of parents and social organisations as well as teachers. This situation mainly affects areas undergoing depopulation, especially rural areas, but also central districts of large cities in Poland.

One of the possibilities to avoid the liquidation of a public school and maintain its accessibility is its transfer to a private operator, in accordance with the Educational System Act of 12 February 2009. The transfer can only concern a school attended by no more than 70 pupils, and only on approval of the Superintendent of Education. As a result of the legal possibility of schools being taken over by non-public operators, the market of educational services run by community and religious organisations as well as legal and natural persons keeps developing rapidly and is highly competitive with public schools.

The possibility of a school transfer to a non-public operator has many benefits. First of all, it allows changing the school operator, which leads to a reduction in public outlays for education. The transfer often prevents the liquidation of small schools. The negative aspects include in particular (Sześciło 2014: 5-13):

- imprecise regulations of the school transfer,

- no precisely defined selection process of new school operators (experience, budget), and

- no legal regulations about preparing an efficiency analysis by communes concerning school closures.

The main difference between a public and a non-public school is that the director of a public school is obliged to verify each year if its pupils receive compulsory schooling. It does not apply to the director of a non-public school. Public schools are basically free of charge. In non-public schools education can also be free, or parents may have to pay a tuition. Recruitment to a public school is based on the principle of universal accessibility, but non-public schools have their own regulations laid down in their statutes. The Teacher's Charter is applied in a public school, and in a non-public one, not. In a public school it is not possible to delete a pupil from the list, but non-public schools have their own regulations in this respect.

It should be mentioned that private schools offer complements to public education. The coexistence of public and non-public education is one of the pillars of the Polish educational system and it can be a remedy for the current demographic problems.

Table 3. Comparison of public and non-public education - main features.

\begin{tabular}{|c|c|c|}
\hline Feature & Public & Non-public \\
\hline school operator & $\begin{array}{l}\text { local and governmental authorities, } \\
\text { private bodies }\end{array}$ & $\begin{array}{l}\text { foundations, associations, companies, } \\
\text { church, private bodies }\end{array}$ \\
\hline compulsory education & yes & no \\
\hline cost of education & free of charge & free of charge or paid (tuition) \\
\hline recruitment & on principle, universal accessibility & own principles laid down in school statute \\
\hline financing & local government budget & local government budget + tuition \\
\hline Teacher's Charter & applied & not applied \\
\hline deletion from list of pupils & not possible & possible \\
\hline $\begin{array}{l}\text { free handbook of Ministry of } \\
\text { National Education }\end{array}$ & $\begin{array}{l}\text { if not - other book financed by com- } \\
\text { mune }\end{array}$ & $\begin{array}{l}\text { if not - other handbook financed by school } \\
\text { operator }\end{array}$ \\
\hline
\end{tabular}

Source: own compilation. 


\section{From a local to a metropolitan educational system: the case of the Poznań agglomeration}

The fast growth of big cities and their surroundings as well as urban residents' mobility have increased especially in the recent years. This has shown that social needs go beyond administrative borders of cities, communes and poviats. The location of schools cannot be decided in isolation from the socio-economic reality, including demography, and associated with changes in a population's age structure and the migration of citizens.

Most of the Polish largest cities currently undergo a suburbanisation process bringing great changes to the population distribution. Residents of large cities migrate to suburban areas looking for better living conditions. This concerns mainly young people who set up families. Demographic changes in agglomeration areas affect the social demand for educational services that is usually
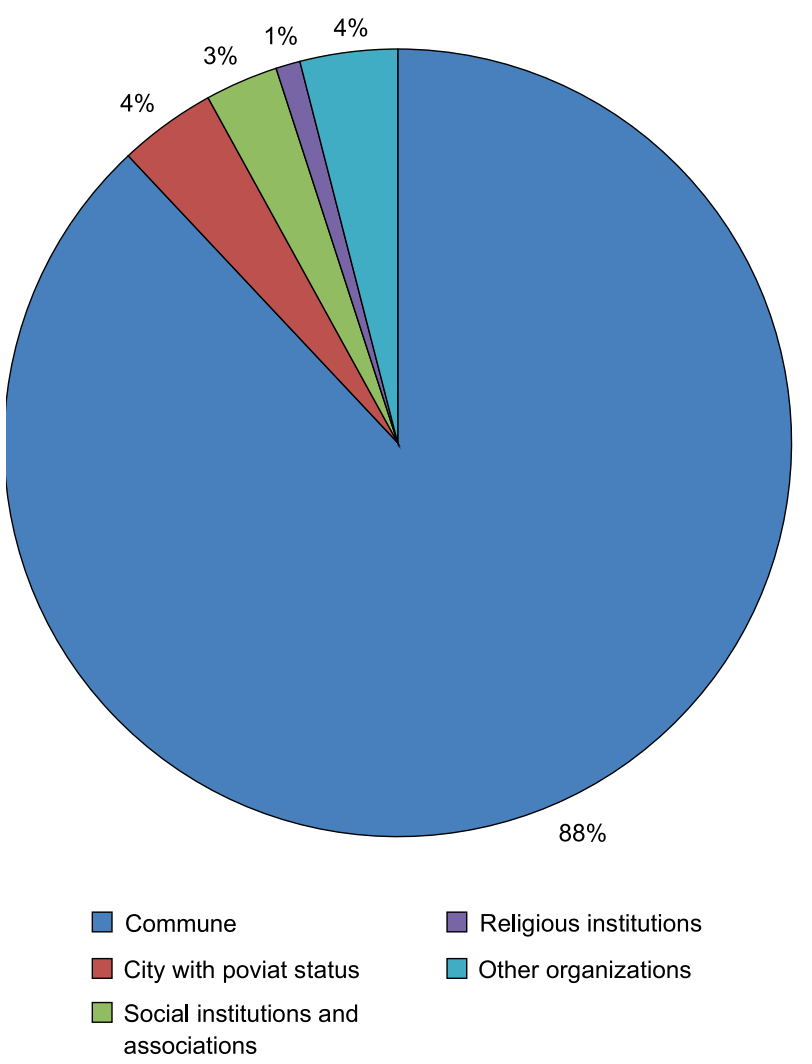

Fig. 3. Structure of pupils in primary schools in Poznań agglomeration by school-running authority (2014).

Source: own compilation. stronger in the rapidly developing suburbs than in the shrinking city centres.

One of the biggest agglomerations in Poland is the Poznan agglomeration, situated in the western part of the country, with 900 thous. inhabitants. The process affecting the spatial distribution of its population is suburbanisation, very intensive in the last fifteen years. The sharpest decrease in the number of inhabitants characterises the centre of Poznan - the old city districts, and the steepest increase, poviats situated close to the city: Dopiewo, Komorniki, and Luboń. Changes in the distribution of the population in the Poznan agglomeration have led to an increase in the demand for educational services in the suburban area and a decrease in the core city.

Poznań is an important educational centre in the Wielkopolska region. In the school year 2013/2014 there were 177 primary schools in the Poznan agglomeration (excluding special schools and schools for adults). A vast majority of them are run by the municipal government (142 schools). Over the past 10 years the school network in the agglomeration has undergone a transformation resulting mainly from demographic factors. During this period the total number of primary schools in the agglomeration grew from 174 to 177 , while the number of schools run by communes decreased from 152 to 142 .

A significant increase in the number of primary schools over the last 10 years can be seen in the non-public sector. In 2004 there were 15 primary schools in the Poznan agglomeration run by non-public operators, while by 2014 their number had grown to 28. Non-public schools managed by foundations, associations, religious organisations, natural or legal persons, and higher education institutions are mostly concentrated in Poznan - the core city of the Poznan agglomeration (Fig. 4). The largest number of pupils in the agglomeration still attend public schools: primary schools run by a local commune $(44,884$, or $88 \%)$ and the poviat $(1,964$, or $4 \%)$, but the growing number of non-public schools causes changes in the structure of students attending schools managed by different operators (Fig. 3). In 2014, $8 \%$ of pupils went to primary schools run by social, religious or other organisations.

The problem of the school network organisation, their spatial accessibility and the quality of education requires coordination and a long-term 


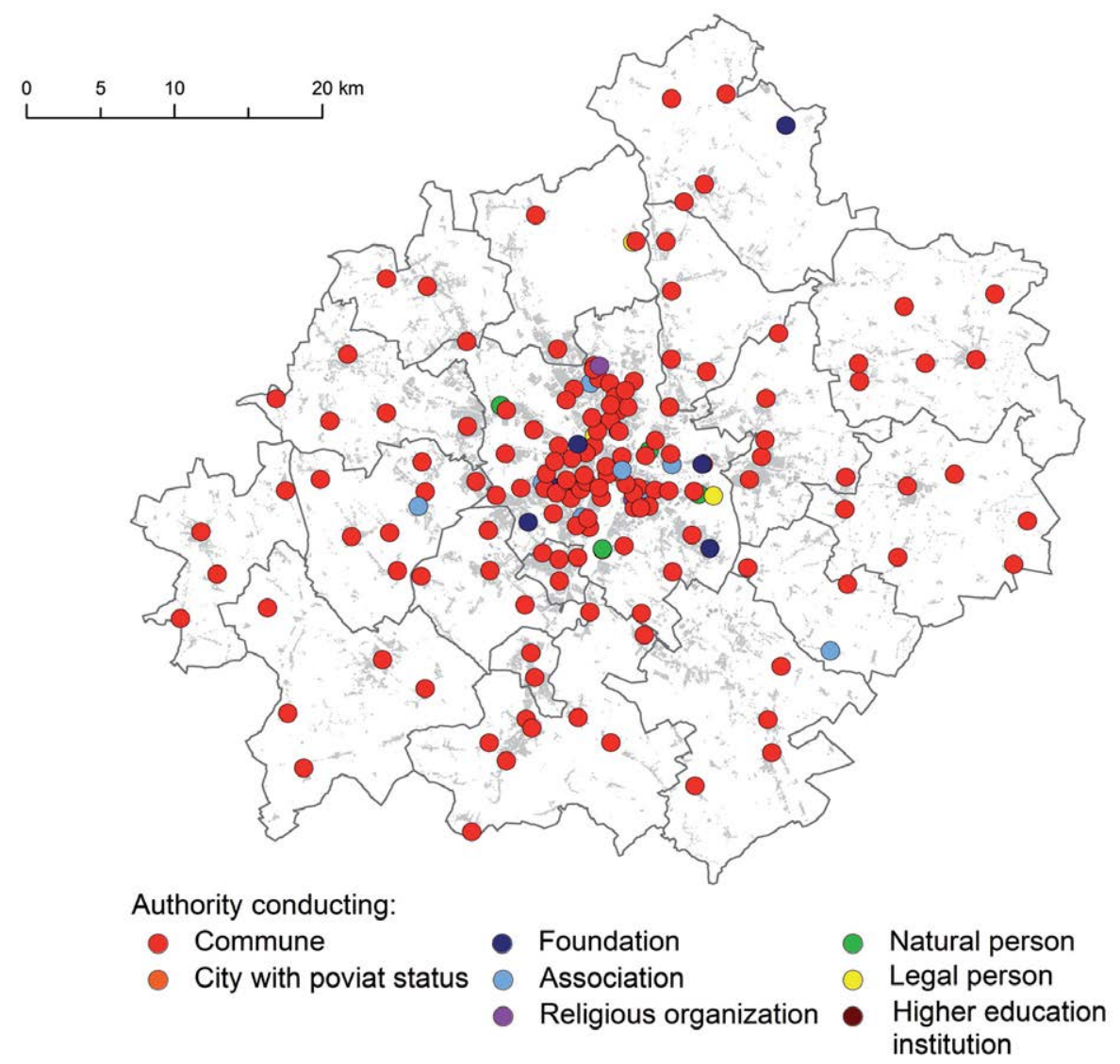

Fig. 4. Spatial distribution of primary schools in the Poznań agglomeration (2014). Source: own compilation.

educational policy for the whole agglomeration. The main objective of a common educational policy should be good accessibility of schools at all levels. Attention should be paid to local determinants, particularly demographic ones, in order to adapt the educational offer to the current needs of residents. In the Polish law no arrangements have yet been made with regard to education at the metropolitan level, but due to the rapid development of suburban areas new legal regulations are badly needed.

\section{Conclusions}

The current state of the Polish educational system is a result of a long-term socio-economic transformation as well as the decentralisation and delegation of public tasks to the local level. Since the 1990s, the Polish school system has constantly been transformed; new reforms and legal instruments keep being introduced in order to adapt it to the current situation. Today, local governments' main challenge is to face the causes and effects of demographic changes brought about by a decrease in the number of children and young people in schools, and to maintain a rational school network.

The systematically growing number of non-public schools in Poland is a significant factor influencing the development of Polish education. In the case of the Poznan agglomeration, it should be emphasised that non-public schools exist as an alternative to public schools. What is significant at both the local and the national level, the taking over of small public schools in areas of a population decline often prevents them from being liquidated. It should be emphasised that this process has an extremely strong impact on the operation of local communities and manifests itself in their protests.

Despite the fact that the important role of metropolitan areas was confirmed in the state's development policy, adequate instruments of public services in the area of education governance have not been established so far. The integration 
of tasks at the agglomeration level in Poland has a bottom-up character, and due to the scale of problems, metropolitan cooperation is focused mainly on transport and public utility issues and it should be emphasised that it is getting better. Unfortunately, the topic of the organisation of educational services in metropolitan areas is not legally regulated and the experience of Polish self-governments is still poor.

Challenges to Polish education will continue to be posed by demographic problems, which, as forecasts indicate, will increase over the next few years. Therefore, it is necessary to estimate the future number of children and young people in administrative units, and to plan steps related to the organisation of education at the local and metropolitan levels. As a result, decisions taken at the local level will play a significant role in the consolidation of local educational markets.

\section{References}

Centralna Komisja Egzaminacyjna, 2015. O egzaminie gimnazjalnym (On the examination to a lower-secondary school). Online: http://www.cke.edu.pl/ index.php/ egzamin-gimnazjalny-left/2013-07-27-10-19-18 (accessed 21 February 2015)

Council of the European Union, 2008. Conclusions of the Council and of the Representatives of the Governments of the Member States, meeting within the Council of 21 November 2008 on preparing young people for the 21st century: An agenda for European cooperation on schools (2008/C 319/09). Online: http:// eur-lex.europa.eu/ LexUriServ/LexUriServ.do?uri = OJ:C:2008:319:0020:0022:EN:PDF (accessed 21 February 2015).

Dolata R., 2005. Najważniejsze wyzwania stojace przed polska oświata (Major challenges facing Polish education). Instytut Spraw Publicznych, Warszawa: 2-6.
European Commission, 2014a. Compulsory education in Europe 2014/2015: 5. Online: http://eacea.ec.europa.eu/ education/eurydice/documents/facts_and_figures/ compulsory_education_EN.pdf (accessed 21 February 2015).

European Commission, 2014b. The structure of European educational systems 2014/2015: Schematic diagrams. Online: http://eurydice.org.pl/wp-content/uploads/ 2014/11/education_structures_EN.pdf (accessed: 21 February 2015).

Eurydice, 2012. Kluczowe dane o edukacji w Europie 2012 (Key data on education in Europe). Online: http:/ / eurydice.org.pl/wp-content/uploads/2012/10/KD_2012_ PL.pdf (accessed 22 February 2015).

Eurydice, 2014. The system of education in Poland. Foundation for the Development of the Educational System. Warsaw.

Kuźnik F., 2012. Polityka rozwoju i zarzadzanie ustugami publicznymi w strukturach samorzadowych (Development policy and public services management in local government structures). Studia KPZK PAN CXLIII, Warszawa.

Herbst M. (ed.), 2012. Decentralizacja oświaty (Decentralisation of education). Biblioteczka Oświaty Samorządowej, Warszawa.

Mitch D., 2004. School finance. In: Johnes G., Johnes J. (eds), International Handbook on the Economics of Education. Edward Elgar Publishing, Northampton.

OECD, 2010. Impact of the 1999 education reform in Poland. Online: http://www.oecd-ilibrary.org/doc server/download $/ 5 \mathrm{kmbjgkm1m9x.pdf?expires=1424547}$ $178 \& \mathrm{id}=\mathrm{id} \&$ accname $=$ guest $\&$ checksum $=$ AD21DFE80CAC37C18ED2265175BF60A0 (accessed 21 February 2015).

OECD, 2014a. Education at a glance. Online: http://www. oecd.org/edu/Education-at-a-Glance-2014.pdf (accessed 22 February 2015).

OECD, 2014b. PISA 2012 results in focus. What 15-year-olds know and what they can do with what they know. Online: http://ww.oecd.org/pisa/keyfindings/pisa-2012-results-overview.pdf (accessed 22 February 2015).

Przyszczypkowski K., 2010. Polityka oświatowa samorządów (Educational policy of local governments). In: Korolewska M., Osiecka-Chojnacka J. (eds), Polityka oświatowa. Biuro Analiz Sejmowych 2(22), Warszawa: 41-63.

Sześciło D., 2014. O wątpliwościach wokół powierzania prowadzenia szkół samorządowych. Samorząd Terytorialny 3: 5-13. 